\title{
EVALUATION OF CERTAIN PESTICIDE MIXTURES FOR THEIR MUTAGENICITY USING AMES Salmonella typhimurium - REVERSE MUTATION ASSAY
}

\author{
B. Reddi Bhargavi ${ }^{1}$, Ravi Kumar VELLANKI ${ }^{1}$, Jagadeeswara Reddy Kanala ${ }^{2 *}$ \\ ${ }^{1}$ Department of Biotechnology, Vignan University, Vadlamudi, Guntur-522213, AP, India \\ ${ }^{2}$ Sugen Life Sciences Pvt.Ltd, Tirupati - 517502, AP, India
}

Received - October 25, 2019; Revision - December 14, 2019; Accepted - December 22, 2019

Available Online - December 25, 2019

DOI: http://dx.doi.org/10.18006/2019.7(6).606.612

KEYWORDS
Salmonella typhimurium
Mutagenicity
Pesticide mixture
Ecosystem
S9 mixture

\begin{abstract}
In this study, the mutagenic effects of two different pesticide mixtures Deltamethrin $1 \%$ + Triazophos $35 \%$ EC (D+T) and Profenofos 40\% EC + Cypermethrin 4\% EC (P+C), used widely in agriculture, have been investigated by using bacterial reverse mutation test system namely, Ames/Salmonella typhimurium test. Five tester strains of Salmonella typhimurium (TA98, TA100, TA102, TA1535 and TA1537) were employed in current study. A range finding study was conducted to assess the cytotoxic effect of the pesticide mixtures by Pre-incubation method employing two tester strains TA98 and TA100. Seven test concentrations in duplicate viz., 78, 156, 313, 625, 1250, 2500 and $5000 \mu \mathrm{g} / \mathrm{plate}$ in the presence and absence of metabolic activation (10\% S9 mix) was used in current study. Based on the cytotoxicity data, mutagenicity evaluation (Main Study by Pre-incubation method) was performed employingfive tester strains (TA100, TA102, TA1535, TA98 and TA1537). Results of experiments were compared with positive and negative control groups' data. Compared to solvent control, no marked or consistent differences in the number of revertant colonies were observed in any concentration of D+T (EC), $\mathrm{P}+\mathrm{C}(\mathrm{EC})$ in all the tester strains with and without exogenous mammalian S9 activation system. Based on study results it can be concluded that both $\mathrm{D}+\mathrm{T}(\mathrm{EC})$ and $\mathrm{P}+\mathrm{C}(\mathrm{EC})$ are non mutagenic and non-cytotoxic against $S$. typhimurium tester strains both in the presence and absence of metabolic activation system up to the dose $5000 \mu \mathrm{g} /$ plate.
\end{abstract}

* Corresponding author

E-mail: kjreddy32@gmail.com (Jagadeeswara Reddy Kanala)

Peer review under responsibility of Journal of Experimental Biology and Agricultural Sciences.

Production and Hosting by Horizon Publisher India [HPI] (http://www.horizonpublisherindia.in/).

All rights reserved.
All the articles published by Journal of Experimental Biology and Agricultural Sciences are licensed under a Creative Commons Attribution-NonCommercial 4.0 International License Based on a work at www.jebas.org.

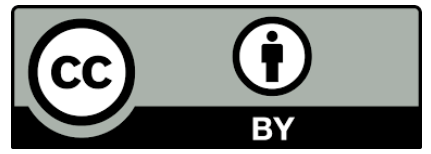




\section{Introduction}

Pesticides when used carefully and in appropriate dose can be useful in agriculture to increase crop yield but excess and random usage of these can damage human health and cause unintentional complications throughout the world (Akyil et al., 2017). Despite several advantages of using pesticides in agriculture, most of them pose a potential hazard to air, water and food that can lead to serious health problems for humans and ecosystems (Jamil et al., 2004). Adverse effects pesticides to humans can be determined different animal models, but it is always a difficult task to evaluate the impact of these complex chemicals on the ecosystem.

If the pesticides are applied in a mixture of two or three, it became more difficult to evaluate the adverse effect of these pesticides. A simple classification of complex mixtures does not warrant their effects on the various biological systems because a mixture of chemicals alters the toxicity of individual substances, this might happened due to the potential interactions between these chemicals. Further, active ingredients of pesticides can also exhibit different behaviors such as additives, synergistic, potentiating or antagonistic effects when separated or mixed (Llorente et al., 2012; Beyer et al., 2014).

There is a complicated nature of pesticides released into the environment, which makes the investigation very difficult to characterize their genotoxic and carcinogenic potential (Bull et al., 2006). Regulatory requirements for the use of pesticide mixtures are based on separate toxicological tests of the individual pesticides in the mixture and not on the mixture's combined toxic effects. Several research groups and international risk assessment bodies have addressed some general principles that demonstrate how substances with different toxicological properties can act either through a synergistic, additive or antagonistic mode of action. In practice, humans and animals are exposed to complex and variable chemical compound combinations (Rietjens \& Alink, 2006).

In a multiple chemical exposure situation, the single chemicals may act independently as in a single exposure, or a number of chemicals may interact to modulate the effects of total multiple exposures. In general, approximately $95 \%$ of all chemical studies are conducted on individual chemicals (Carpenter et al., 2002). There are very few studies on the extent to which chemical mixtures have an impact, especially on the environment. Pesticides genetic toxicity is determined by several variables such as: (i) their biological accumulation or environmental degradation; (ii) their human metabolism; (iii) their reactivity to cellular components such as DNA, RNA, and proteins.

In a short-term test system, Jurs et al. (1983) published quantitative and qualitative research on the mutagenic potencies of certain pesticides and other compounds. In order to compare the capabilities of chosen short-term assays to detect and confirm the genotoxic activity of pesticides, Waters et al. (1980) widely worked on the genotoxic activity shown by number of pesticides presenting various chemical structures in separate test systems. Three kinds of genetic DNA damage can be identified in the shortterm bioassays: (i) gene or point mutations; (ii) primary DNA damage and repair; (iii) chromosomal changes (Ames, 1982).

The Salmonella mutagenicity test is the most commonly used short-term test for testing mutagens and environmental compounds (Ames et al., 1975). His operon contains various kinds of mutations in these Salmonella strains (Maron \&Ames, 1983). The assay can determine if mutations were frame shifts or base pair replacements by its operon's reverse mutation. Such mutations lead in the formation of colonies on his "agar plates." However, the Ames test demonstrates that the frequency of spontaneous reverting colonies is high, if not slow $(48 \mathrm{~h})$, and that histidine contaminated samples are not appropriate for testing.

In view of the above, in present research, the bacterial reverse mutation test was conducted to evaluate the mutagenic potential of certain pesticide mixtures on salmonella typhimurium test strains by following pre-incubation method both in the presence and absence of metabolic activation system.

\section{Materials and methods}

\subsection{Pesticide mixtures}

The two pesticide mixtures viz., Deltamethrin $1 \%+$ Triazophos 35\% EC and Profenofos 40\% EC + Cypermethrin 4\% EC used in the research were procured locally.

\subsection{Culture}

Salmonella typhimurium bacterial strains TA 98, TA 100, TA 102 , TA 1535 and TA 1537 was obtained from Defense Research and Development Establishment (DRDE), Gwalior, India and were stored as frozen permanent stock in cryo vials with Oxoid nutrient broth no. 2 and $9 \%$ DMSO at $-80^{\circ} \mathrm{C}$. Prior to experiment overnight cultures were prepared by transferring a small quantity of frozen culture to a flask containing Oxoid nutrient broth no.2 and incubated in a shaking water bath at 100 strokes for 14 hours at $37 \pm 2^{\circ} \mathrm{C}$. $1-2 \times 10^{9} \mathrm{cfu} / \mathrm{ml}$ of cells were used for the study.

\subsection{Positive control}

To ensure both strain integrity and effectiveness of the metabolic activation system, strain specific positive controls (known mutagens) were included in each method both with and without S9 mix (Table.1). All known mutagens were obtained from Sigma, India. 
Table 1 List of Positive controls

\begin{tabular}{|c|c|c|c|c|c|}
\hline Method & Mutagen & $\mathrm{CAS} \mathrm{N}^{\circ}$ & Solvent & $\begin{array}{l}\text { Conc. per } \\
\text { plate }(\mu \mathrm{g})\end{array}$ & $\begin{array}{c}\text { Responding } \\
\text { Salmonella strains }\end{array}$ \\
\hline $\begin{array}{c}\text { Non-Activation } \\
\text { (-S9) [Direct acting } \\
\text { mutagens] }\end{array}$ & $\begin{array}{c}\text { Mitomycin C } \\
\text { Sodium azide } \\
\text { 2-Nitrofluorene } \\
\text { 9-Aminoacridine }\end{array}$ & $\begin{array}{c}50-07-7 \\
26628-22-8 \\
607-57-8 \\
90-45-9\end{array}$ & $\begin{array}{l}\text { Water } \\
\text { Water } \\
\text { DMSO } \\
\text { DMSO }\end{array}$ & $\begin{array}{c}0.5 \\
1 \\
10 \\
50\end{array}$ & $\begin{array}{c}\text { TA102 } \\
\text { TA1535, TA100 } \\
\text { TA98 } \\
\text { TA1537 }\end{array}$ \\
\hline Activation (+S9) & $\begin{array}{l}\text { Benzo(a)pyrene } \\
\text { (Sigma, India) }\end{array}$ & $50-32-8$ & DMSO & 10 & $\begin{array}{c}\text { TA102, TA1535, } \\
\text { TA100, TA98 } \\
\text { TA1537 }\end{array}$ \\
\hline
\end{tabular}

\subsection{Confirmation of Genotypes}

Genotyping of Salmonella typhimurium strains was performed prior to study initiation to ensure the genetic integrity. The presence of R-factor plasmids (ampicillin and tetracycline resistance) was confirmed by the method of ampicillin and tetracycline resistance followed by $r f a$ mutation confirmed through sensitivity to crystal violet and presence of $u v r B$ mutation was confirmed by demonstrating the sensitivity of the tester strains to UV suggested by Ames et al. (1975).

\subsection{Solubility and Precipitation Test}

Solubility of the pesticide mixtures was determined first by dissolving in distilled water followed by other well-known solvents not limited to DMSO, acetone and ethanol. $50 \mathrm{mg}$ pesticide mixture was completely soluble in $1.0 \mathrm{ml}$ of respective solvent, from this $(50 \mathrm{mg} / \mathrm{ml}) 100 \mu \mathrm{l}$ was mixed with top agar and added to minimal glucose agar (MGA) plate.

\subsection{Preparation of the pesticide mixtures solution}

The pesticide mixtures were prepared shortly prior to treatment of cultures and serial dilutions were done to achieve further lower concentrations. Consistency of the testing solutions was maintained during treatment by thorough vortexing of the preparations.

\subsection{Cytotoxicity Test}

The toxicity of each pesticide mixture was evaluated by performing cytotoxicity test with strains TA 98 and TA 100 . Seven concentrations of pesticide mixtures 5000, 2500, 1250, $625,313,156$ and $78 \mu \mathrm{g} / \mathrm{plate}$ were tested for toxicity in duplicate both in the absence and presence of metabolic activation system ( $\mathrm{S} 9 \mathrm{mix}$ ). $0.1 \mathrm{ml}$ of $\mathrm{DMSO} /$ plate used as negative control. $0.1 \mathrm{ml}$ pesticide mixture at each dose level (treatment plates) or $0.1 \mathrm{ml}$ of DMSO (negative control plates), $0.5 \mathrm{ml}$ of $\mathrm{S} 9 \mathrm{mix}$ (for test in the presence of metabolic activation) or $0.5 \mathrm{ml}, 0.1 \mathrm{M}$ sodium phosphate buffer (for test in the absence of metabolic activation), $0.1 \mathrm{ml}$ bacterial suspension $\left(1-2 \times 10^{9} \mathrm{cfu} / \mathrm{ml}\right)$ were added to each tube and pre incubated at $37^{\circ} \mathrm{C}$ for 15 minutes prior to mixing with the $2 \mathrm{ml}$ top agar. The mixture was poured on minimal glucose agar (MGA) plates. After solidification the plates were incubated in inverted position for a period of 48 hours at $37 \pm 2{ }^{\circ} \mathrm{C}$. Number of revertant colonies per plate was counted by using colony counter and bacterial background lawn was observed with microscope low power objective.

\subsection{Mutagenicity Test}

Based on the cytotoxicity data mutagenicity test was performed by following pre-incubation method with 5 tester strains (TA 98, TA 100, TA 102, TA 1535 and TA 1537), at doses 5000, 2500, $1250,625,313 \mu \mathrm{g} / \mathrm{plate}$, in triplicates both in the absence and presence of metabolic activation system. Negative control plates are treated with $0.1 \mathrm{ml}$ of $\mathrm{DMSO} /$ plate. Positive control plates for each strain both in the absence and presence of metabolic activation system are treated with known positive controls in triplicates (Table 2). After treatment, plates were incubated in inverted position for a period of 48 hours at $37 \pm 2^{\circ} \mathrm{C}$. Colony counts were compared with negative control.

2.7 Statistics: SPSS 16.0 software was used for statistical analysis.

\section{Results}

Ames test is one of the most reliable short-term bacterial test system has been used to detect mutagenic activity of pesticides via the detection of various types of gene mutations such as base-pair substitutions (TA100 and TA1535), frame-shift mutations (TA98 and TA97) and transition or transversion events (TA102).

\subsection{Genotyping:}

The genotypes of all the tester strains were assessed to be intact. All the strains showed histidine and biotin dependence (except TA 102) which indicate the mutation in His gene and uvr B deletion. TA102 strain has shown biotin independence, no uvrB deletion. Zone of inhibition indicates that strains are having leaky lipopolysaccharide envelope. Resistance to antibiotics (Ampicillin and Tetracycline) indicates that plasmid pKM101 and pAQ1 carrying by the strains TA98, TA100 and TA102 (Table 2). 
Table 2 Genotype confirmations of tester strains

\begin{tabular}{|c|c|c|c|c|c|}
\hline Test & TA 98 & TA 100 & $\begin{array}{l}\text { Strain } \\
\text { TA } 102\end{array}$ & TA 1535 & TA 1537 \\
\hline Histidine dependence & - & - & - & - & - \\
\hline UVrB mutation & - & - & - & - & - \\
\hline Histidine and Biotin dependence & + & + & + & + & + \\
\hline Rfa mutation & $\mathrm{Z}$ & $\mathrm{Z}$ & $\mathrm{Z}$ & $\mathrm{Z}$ & $\mathrm{Z}$ \\
\hline Ampicillin resistance & + & + & + & - & - \\
\hline Tetracycline resistance & - & - & + & - & - \\
\hline
\end{tabular}

-=No growth, +=Growth, Z=Zone of inhibition

Table 3 Cytotoxicity analysis of selected pesticides mixture on S. typhimurium strains TA98 and TA 100

\begin{tabular}{|c|c|c|c|c|c|}
\hline \multirow{3}{*}{ Test Materials } & \multirow{3}{*}{ Dose $(\mu \mathrm{g} /$ plate $)$} & \multicolumn{4}{|c|}{$\mathrm{AHR} \pm \mathrm{SD} *$} \\
\hline & & & & & \\
\hline & & $\mathrm{S} 9(+)$ & S9(-) & $\mathrm{S} 9(+)$ & S9(-) \\
\hline \multirow{7}{*}{$\begin{array}{c}\text { Deltamethrin } 1 \% \\
+ \\
\text { Triazophos 35\% EC }\end{array}$} & 78 & $39 \pm 5.39^{*}$ & $39 \pm 2.83^{*}$ & $129.5 \pm 0.71 *$ & $119 \pm 2.83^{*}$ \\
\hline & 156 & $40 \pm 2.93 *$ & $42 \pm 1.87^{*}$ & $129 \pm 7.07 *$ & $124 \pm 7.07 *$ \\
\hline & 313 & $48 \pm 0.71 *$ & $46 \pm 0.69 *$ & $120 \pm 1.41 *$ & $130 \pm 9.19 *$ \\
\hline & 625 & $35 \pm 0.77 *$ & $40 \pm 1.98^{*}$ & $130 \pm 2.83 *$ & $123 \pm 5.66^{*}$ \\
\hline & 1250 & $39 \pm 0.54 *$ & $45 \pm 3.82 *$ & $131 \pm 5.66^{*}$ & $120 \pm 9.90^{*}$ \\
\hline & 2500 & $51 \pm 7.05^{*}$ & $38 \pm 5.32 *$ & $119.5 \pm 2.12 *$ & $114 \pm 7.07 *$ \\
\hline & 5000 & $46 \pm 1.95^{*}$ & $48 \pm 0.71^{*}$ & $130 \pm 4.24 *$ & $124 \pm 3.54 *$ \\
\hline $\begin{array}{l}\text { Solvent Control } \\
\text { (DMSO) }\end{array}$ & & $54 \pm 4.24$ & $53 \pm 5.66$ & $183 \pm 5.66$ & $162 \pm 4.24$ \\
\hline \multirow{7}{*}{$\begin{array}{c}\text { Profenofos 40\% EC } \\
+ \\
\text { Cypermethrin 4\% EC }\end{array}$} & 78 & $42.5 \pm 7.78^{*}$ & $44.5 \pm 2.12 *$ & $139.5 \pm 9.19 *$ & $122.5 \pm 2.12 *$ \\
\hline & 156 & $38.5 \pm 2.12 *$ & $42 \pm 4.24 *$ & $142 \pm 7.07 *$ & $132 \pm 5.66^{*}$ \\
\hline & 313 & $36 \pm 8.49 *$ & $40 \pm 5.66^{*}$ & $148.5 \pm 9.19^{*}$ & $128.5 \pm 4.95^{*}$ \\
\hline & 625 & $43.5 \pm 3.54 *$ & $31 \pm 1.41^{*}$ & $132.5 \pm 0.71 *$ & $122.5 \pm 4.95 *$ \\
\hline & 1250 & $42.5 \pm 7.78^{*}$ & $43 \pm 2.83^{*}$ & $149 \pm 2.83 *$ & $111 \pm 2.83 *$ \\
\hline & 2500 & $30.5 \pm 0.71 *$ & $46 \pm 1.41^{*}$ & $141 \pm 2.83 *$ & $118 \pm 4.24 *$ \\
\hline & 5000 & $41 \pm 4.24 *$ & $43 \pm 1.41 *$ & $153.5 \pm 2.12 *$ & $118.5 \pm 9.19^{*}$ \\
\hline $\begin{array}{l}\text { Solvent Control } \\
\text { (DMSO) }\end{array}$ & & $47.5 \pm 2.12$ & $47 \pm 1.41$ & $150 \pm 1.41$ & $135.5 \pm 4.95$ \\
\hline
\end{tabular}

$A H R=$ Average Histidine Revertants, $S D=$ Standard deviation * Statistically significant at $P<0.05 ; S 9(+)$ with $S 9$ mix and $S 9(-)$ without $S 9$ mix

\subsection{Cytotoxicity Test}

For the initial assessment of the cytotoxic effect of the two pesticides mixtures, seven concentrations, viz., 78, 156, 313, 625, 1250, 2500 and $5000 \mu \mathrm{g} /$ plate were chosen employing against two tester strains (TA98 and TA100) with the presence and absence of metabolic activation (S9 mix). After treatment, the non-interfering precipitate was observed in 5000 and $2500 \mu \mathrm{g} /$ plate both in the cases of presence and absence of $\mathrm{S} 9$ mix. No cytotoxicity was observed by inhibition of the background lawn (Table 3). The average revertant colony numbers in solvent control for pesticide mixture D+T (EC) was $54 \pm 4.24$ for TA98 and $183 \pm 5.66$ for TA100 in the presence of S9 mix where as $53 \pm 5.66$ and $162 \pm 4.24$ in the absence of S9 mix, respectively. Spontaneous revertantscolonies obtained were within the normal values for the two strains examined. Some concentrations of D+T (EC) lowered the spontaneous reversion slightly. On the contrary, the plates with the pesticide mixture $\mathrm{P}+\mathrm{C}(\mathrm{EC})$ were $47.5 \pm 2.12$ for TA98 and $150 \pm 1.41$ for TA100 in the presence of $S 9$ mix and $47 \pm 1.41$ and $135.5 \pm 4.95$ in the absence of $S 9$ mix, respectively. Cytotoxicity 
test results explain that up to $5000 \mu \mathrm{g} /$ plate pesticide mixtures are non-cytotoxic in this test.

\subsection{Mutagenicity Test}

Based upon cytotoxicity results, $5000 \mu \mathrm{g} / \mathrm{plate}$ is decided as the highest dose for the mutagenicity test. The relationship between the dose concentrations and each individual strain was calculated using Karl Pearson's correlation coefficient and was tested using Student's t-test for their significance at $\mathrm{p}<0.05$. It was found that there is no significant increase or decrease in the colony count of each strain. A regression analysis was also performed using leas squares method and found that the regression coefficients were no differing significantly at $\mathrm{p}<0.05$ between the dose concentration and individual strain colony count values.

In the mutagenicity confirmatory assay, with $\mathrm{S} 9$, compared to the solvent control, AHR of TA 98 and TA 1537 exposed to various concentrations of D+T (EC) did not change significantly, whereas AHR of TA 100, TA 102 and TA 1535 decreased in 1250 and $2500 \mu \mathrm{g} /$ plate. Without S9, compared to the solvent control, AHR of all tester strains decreased in $5000 \mu \mathrm{g} /$ plate (in 1537, AHR decreased in $2500 \mu \mathrm{g} /$ plate also) AHR markedly increased in all the tester strains exposed to the positive control (Table 4).

As well as in $\mathrm{P}+\mathrm{C}$ (EC) when treated with $\mathrm{S} 9$ did not change significantly, whereas AHR of TA 100, TA 102 and TA 1535 decreased in 1250 and $2500 \mu \mathrm{g} /$ plate. Without $\mathrm{S} 9$, compared to the solvent control, AHR of all tester strains decreased in 313 to 5000 $\mu \mathrm{g} / \mathrm{plate}$. When treated with positive control AHR markedly increased in all the tester strains (Table 5).

\section{Discussion}

In the present study, two pesticides mixture which widely used in India are evaluated for their potential genotoxicity in vitro using Ames assay. Ames bacterial reverse mutation test is preferably used to detect the point and frame-shift mutations, which alter the nucleotide sequence of the DNA (Ames et al., 1975). There is no sufficient evidence in relation to mutagenicity of pesticide mixtures used in this study. This study will be the first report on detecting the mutagenic effects of $\mathrm{D}+\mathrm{T}(\mathrm{EC})$ and $\mathrm{P}+\mathrm{C}(\mathrm{EC})$ using Ames test in S. typhimurium strains in vitro. WHO (1990a) reported that deltamethrin alone is non mutagenic to Ames bacterial test system. Similarly, International program on chemical safety (INPCS) reported that triazophos was also non mutagenic to Ames bacterial test system (WHO, 1990b). However, as per joint FAO/WHO meeting on pesticide residues, Profenophos showed a negative result in the Ames assay (WHO, 2007). In WHO (2015) specifications report, cypermethrin is considered to be negative in the Ames assay. The results of current study revealed that combination of these pesticides is non-mutagenic at the experimental conditions employed.

\section{Conclusion}

There is no sufficient evidence in relation to $\mathrm{D}+\mathrm{T}(\mathrm{EC})$ and $\mathrm{P}+\mathrm{C}$ (EC) cytotoxicity and mutagenicity. This study is the first report on detecting the mutagenic effects of D+T (EC) and P+C (EC) using Ames test in $S$. typhimurium strains in vitro. Based on study results it can be concluded that, both $\mathrm{D}+\mathrm{T}(\mathrm{EC})$ and $\mathrm{P}+\mathrm{C}(\mathrm{EC})$ were non mutagenic and non-cytotoxic against S.typhimurium tester strains in the presence or absence of metabolic activation system up to the dose $5000 \mu \mathrm{g} /$ plate.

\begin{tabular}{|c|c|c|c|c|c|c|c|c|c|}
\hline \multirow{2}{*}{$\begin{array}{l}\text { Tester } \\
\text { strains }\end{array}$} & & \multicolumn{6}{|c|}{ Test concentration $(\mu \mathrm{g} /$ plate $)$} & \multirow{2}{*}{$\begin{array}{c}\text { Solvent control } \\
\text { (DMSO } 0.1 \\
\text { ml/plate) }\end{array}$} & \multirow{2}{*}{$\begin{array}{c}@ \text { positive } \\
\text { control }\end{array}$} \\
\hline & & & 313 & 625 & 1250 & 2500 & 5000 & & \\
\hline \multirow{2}{*}{ TA98 } & \multirow{6}{*}{$\begin{array}{l}\text { 命 } \\
+1 \\
\text { 䍃 }\end{array}$} & $(+\mathrm{S} 9)$ & $40 \pm 2.7 *$ & $41 \pm 4.55^{*}$ & $38 \pm 6.21$ & $43 \pm 6.32 *$ & $41 \pm 3.02$ & $43 \pm 3.21$ & $154 \pm 9.71$ \\
\hline & & $(-S 9)$ & $39 \pm 5.87 *$ & $45 \pm 3.8^{*}$ & $42 \pm 5.68 *$ & $35 \pm 5.41$ & $42 \pm 7.3^{*}$ & $46 \pm 3.01$ & $135 \pm 9.29$ \\
\hline \multirow{2}{*}{ TA 100} & & $(+\mathrm{S} 9)$ & $127 \pm 7.09 *$ & $132 \pm 2.52 *$ & $131 \pm 3.00 *$ & $126 \pm 6.00$ & $128 \pm 3.06$ & $133 \pm 6.03$ & $185 \pm 8.02$ \\
\hline & & $(-\mathrm{S} 9)$ & $110 \pm 5.13^{*}$ & $119 \pm 6.11^{*}$ & $124 \pm 7.00$ & $125 \pm 1.53^{*}$ & $120 \pm 8.50$ & $127 \pm 2.89$ & $176 \pm 6.11$ \\
\hline \multirow{2}{*}{ TA102 } & & $(+\mathrm{S} 9)$ & $283 \pm 29.65 *$ & $364 \pm 36.54$ & $312 \pm 62.69 *$ & $274 \pm 40.64$ & $309 \pm 34.9$ & $346 \pm 52.65$ & $676 \pm 36.04$ \\
\hline & & $(-\mathrm{S} 9)$ & $280 \pm 24.1^{*}$ & $300 \pm 47.03 *$ & $291 \pm 44.6$ & $288 \pm 88.62 *$ & $285 \pm 57.89 *$ & $297 \pm 56.86$ & $650 \pm 38.59$ \\
\hline \multirow{2}{*}{ TA 1535} & & $(+\mathrm{S} 9)$ & $46 \pm 3 *$ & $43 \pm 3.51^{*}$ & $45 \pm 2.52^{*}$ & $44 \pm 3.79$ & $42 \pm 1.53$ & $46 \pm 2.08$ & $137 \pm 11.06$ \\
\hline & & $(-\mathrm{S} 9)$ & $46 \pm 2.52^{*}$ & $44 \pm 4.00^{*}$ & $45 \pm 1.53^{*}$ & $43 \pm 3.51$ & $46 \pm 2.00^{*}$ & $47 \pm 1.53$ & $136 \pm 8.62$ \\
\hline \multirow{2}{*}{ TA 1537} & & $(+\mathrm{S} 9)$ & $10 \pm 3.51^{*}$ & $13 \pm 3.35^{*}$ & $14 \pm 1.57^{*}$ & $12 \pm 5.13$ & $12 \pm 4.49$ & $15 \pm 1.76$ & $66.33 \pm 7.37$ \\
\hline & & $(-\mathrm{S} 9)$ & $9 \pm 2.86^{*}$ & $13 \pm 3.5^{*}$ & $15 \pm 1.31^{*}$ & $12 \pm 2.12$ & $13 \pm 2.88$ & $14 \pm 2.49$ & $54 \pm 4.51$ \\
\hline
\end{tabular}

@ - Positive control with S9 - Benzo(a)pyrene (10 $\mu \mathrm{g} /$ plate) for all five strains (TA100, TA102, TA1535, TA1537 and TA98). @ - Positive

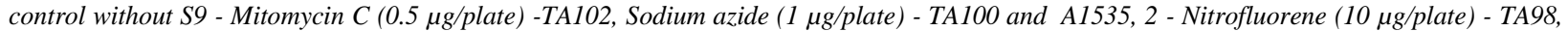
9 - Aminoacridine $(50 \mu \mathrm{g} /$ plate $)$ - TA1537.AHR = Average Histidine Revertants, S.D. = Standard Deviation; S9 (+) with S9 mix and S9 (-) without 59 mix 
Table 5 Mutagenicity analysis of Profenofos 40\% EC + Cypermethrin 4\% EC (P+C) using Salmonella typhimurium strain

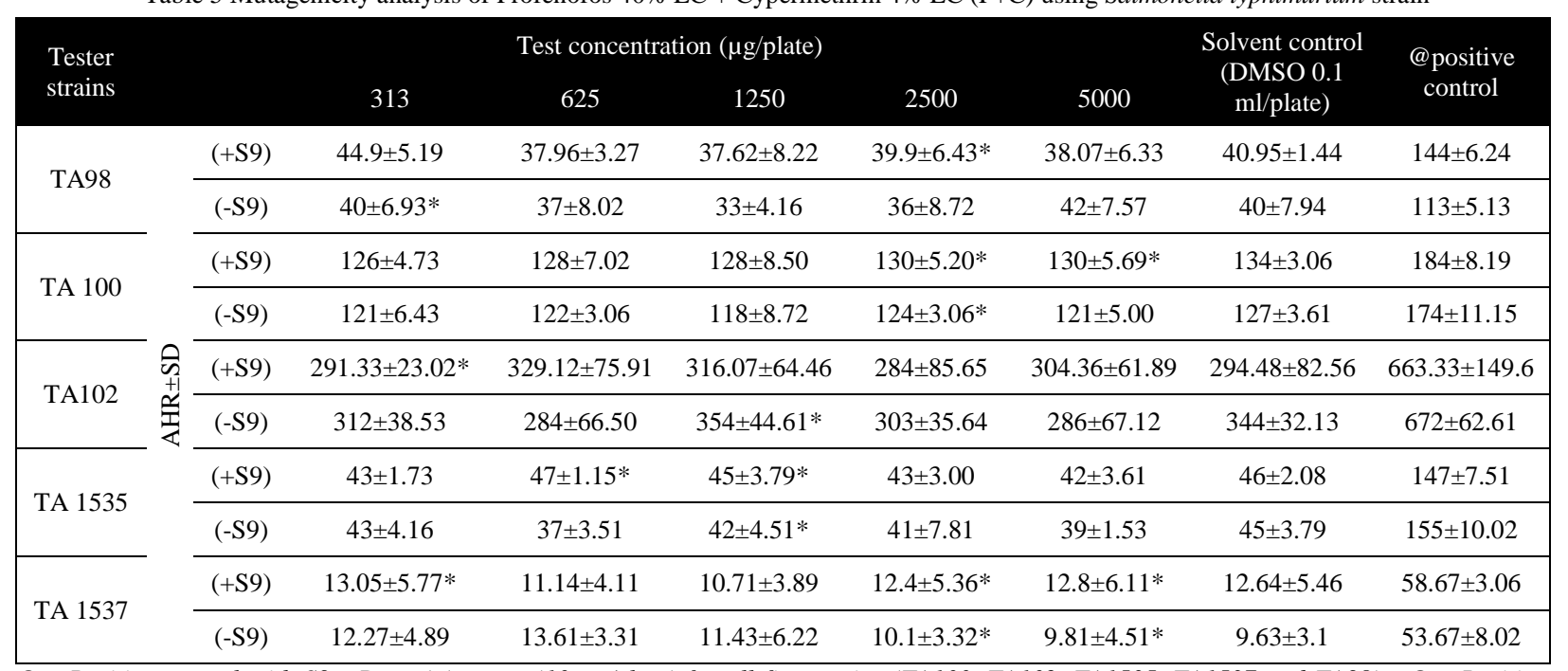

@ - Positive control with S9 -Benzo(a)pyrene (10 $\mu \mathrm{g} /$ plate) for all five strains (TA100, TA102, TA1535, TA1537 and TA98). @ - Positive control without $S 9$ - Mitomycin C $(0.5 \mu \mathrm{g} /$ plate $)$-TA102, Sodium azide $(1 \mu \mathrm{g} /$ plate $)$ - TA100 and A1535, 2 - Nitrofluorene (10 $\mu \mathrm{g} /$ plate $)$ - TA98, 9 - Aminoacridine $(50 \mu \mathrm{g}$ /plate $)-$ TA1537.AHR $=$ Average HistidineRevertants, S.D. $=$ Standard Deviation; S9 (+) with S9 mix and S9 (-) without 59 mix

\section{Conflict of Interest}

Authors hereby declare no conflict of interest.

\section{References}

Akyil D, Konuk M, Eren Y, Liman R, Sağlam E (2017) Mutagenic and genotoxic effects of Anilofos with micronucleus, chromosome aberrations, sister chromatid exchanges and Ames test. Cytotechnology 69:865-874. doi: 10.1007/s10616-017-0099-y.

Ames BN (1982) Mutagens, Carcinogens, and Anti-Carcinogens. In: Raymond FF (Ed.), Genetic Toxicology: An Agricultural Perspective "Basic life sciences' Springer Publication, US 21: 499-508.

Ames BN, McCann J, Yamasaki E (1975) Methods for Detecting Carcinogens and Mutagens with the Salmonella/MammalianMicrosome Mutagenicity Test. Mutation Research 31: 347-364.

Beyer J, Petersen K, Song Y, Ruus A, Grung M (2014) Environmental risk assessment of combined effects in aquatic ecotoxicology: a discussion paper. Marine Environmental Research 96: 81-91.

Bull S, Fletcher K, Boobis AR, Battershill JM (2006) Evidence for genotoxicity of pesticides in pesticide applicators: a review. Mutagenesis 21: 93-103.

Carpenter DO, Arcaro K, Spink DC (2002) Understanding the human health effects of chemical mixtures. Environmental Health Perspectives (Supplement 1) 110: 25-42.
Jamil K, Shaik AP, Mahboob M, Krishna D (2004) Effect of organophosphorus and organochlorine pesticides (Monocrotophos, Chlorpyriphos, Dimethoate and Endosulfan) on human lymphocytes in vitro. Drug and Chemical Toxicology 27: 133-135.

Jurs P, Hasan MN, Herry DG, Stouch TR, Whalen-Pedersen EK (1983) Computer assisted studies of molecular structure and carcinogenic activity. Fundamental and Applied Toxicology 3: 343-349.

Llorente MT, Parra JM, Sanchez-Fortun S, Castano A (2012) Cytotoxicity and genotoxicity of sewage treatment plant effluents in rainbow trout cells (RTG-2). Water Research 46: 6351-6358.

Maron DM, Ames BN (1983) Revised Methods for the Salmonella Mutagenicity Test. Mutation Research 113: 173-215.

Rietjens IM, Alink GM (2006) Future of toxicology-low-dose toxicology and risk-benefit analysis. Chemical Research Toxicology 19: 977-981.

Waters MD, Simmon VF, Michell AD, Jorgenson TA (1980) Anoverview of short-term tests for the mutagenic and carcinogenic potential of pesticides. Journal of Environmental Science and Health 6: 867-906.

WHO (1990a) Environmental Health Criteria, Deltamethrin. Available on http://www.inchem.org/documents/ehc/ehc/ehc97.htm, accessed on 04 August 2019. 
WHO (1990b) Triazophos. Available on

http://www.inchem.org/documents/jmpr/jmpmono/v86pr18.htm, accessed on 05 August 2019.

WHO (2007) Pesticide residues in food 2007 Joint FAO/WHO

Meeting on Pesticide Residues. Available on

http://www.fao.org/fileadmin/templates/agphome/documents/Pests
on_Pesticides/JMPR/Report07/report2007jmpr.pdf, accessed on August 04, 2019.

WHO (2015) who specifications and evaluations for public health pesticides.https://www.who.int/neglected_diseases/vector_ecology /pesticidespecifications/en/Alphacypermethrin_WHO_specs_eval_ Feb_2015.pdf ua=1, accessed on 02 August 2019. 